\title{
Oil and Fat Business of Ukraine: Marketing Orientation for Achieving Competitive Advantages
}

\author{
By Olga Gonchar ${ }^{1 \mathrm{a}}$, Nataliia Zamkova ${ }^{2 \mathrm{~b}}$, Iryna Polishchuk ${ }^{3 \mathrm{~b}}$, Yuriy Dovhan ${ }^{4 \mathrm{~b}}$, \\ Valentyna Sokolovska ${ }^{5 b}$
}

\begin{abstract}
The article examines theoretical approaches to achieving the competitive advantages of Ukrainian oil and fat enterprises in modern market conditions. Special attention is paid to the peculiarities of the use in business management of marketing concepts of business organization, which are oriented at the market, needs of consumers, society and other stakeholders. The most effective results for the enterprises are provided by the implementation of marketing management concepts that are oriented at identifying and meeting consumer demand as well as consideration of the interests of all other stakeholders in the supply chain of oil and fat products, the individual, community and society, i.e. concepts of marketing interaction and holistic marketing.

The supply chain of oil and fat products includes the economic interests of business entities that develop varieties of oil and fat seeds, machinery and technology, supply of resources, production of raw materials, processing, storage and transportation, etc. A key position in the supply chain is occupied by the consumer. The success of the marketing strategy of the enterprise depends on the degree of consideration of the interests of the individual, communities, society and the state.

It is concluded that oil and fat companies in the food industry can gain sustainable competitive advantages due to integration efforts aimed to form agricultural and food clusters in local geographical areas from all stakeholders and relationships in the supply chain of oil and fat products including suppliers, manufacturers, intermediaries, consumers, government and other organizations, etc.
\end{abstract}

Keywords: oil and fat business, marketing orientation, competitive advantages, supply chain, stakeholders, interests, oil and fat cluster.

\section{Introduction}

Oils and fats are an integral part of human nutrition and they hold an important position in both human life and the economy. In recent decades, oil and fat markets have expanded significantly due to the growth of the world population and diversification of food, feed, industrial consumption and biofuels. International markets for oils and fats remain important for the developed countries and crucial for many developing countries as they become more integrated into the world economy.

Ukraine is known to be a country with a long-standing agrarian history. The country has a significant potential for its successful further development. Favorable natural and

\footnotetext{
| ${ }^{1}$ Doctor of Economic Sciences, Professor of the Marketing and Trade Entrepreneurship Department.

2 Doctor of Philosophical Sciences, Professor, Director of the Institute.

${ }^{3}$ Doctor of Economic Sciences, Associate Professor, Head of the Marketing and Advertising Department.

${ }^{4}$ Senior Lecturer of the Marketing and Advertising Department.

${ }^{5}$ Ph.D. in Economics, Associate Professor, Head of the Management and Administration Department.

bVinnytsia Institute of Trade and Economics of Kyiv National University of Trade and Economics, Ukraine.
} 
climatic conditions provide good opportunities for agribusiness to grow effectively many crops, including oilseeds. Ukraine's location in the center of geographical Europe enables to minimize the total costs in the international logistics supply chain of oil and fat products.

Oil and fat companies in Ukraine are one of the few in the national economy that have not reduced their efficiency and have long experienced a positive dynamics of their economic development. Ukrainian producers have significantly increased the volumes of production of oil and fat products, enhanced economic efficiency of production, expanded the assortment and improved product quality.

Gained competitive advantages in the global oil and fat market, stable growing global demand and export orientation in the main segments of oil and fat products allow domestic companies to feel confident in the market. However, the global situation in the oil and fat market, consumer preferences and tastes in the world are changing dynamically and pose new challenges to companies that can be addressed by gaining more sustainable competitive advantages than those already gained due to a marketingoriented approach to business activity.

\section{Literature Review}

Theoretical approaches to managing the formation of competitive advantages of companies were formed and evolved together with the theory of competitiveness. Initially, the focus on the formation of competitive advantages was targeted at the internal environment of the company (Schumpeter, 1912). Later, the emphasis was gradually shifted towards the importance of the influence of external factors on the formation of competitive advantages of companies, including competitive environment and positioning in the industry (Porter, 1985; Ansoff \& McDonnell, 1988).

The change in management approaches to gaining competitive advantages, from traditional management to marketing-oriented management, has occurred historically and gradually by shifting the emphasis from production and product management to strengthening the commercial component of business, and then focusing on researching consumer needs and addressing business ethics (Kotler \& Armstrong, 1991; Dikson, 1997). Market-oriented companies seek to bring more benefits to the consumer than the competitor's offerings, thereby maximizing their own success. Thus, marketing orientation covers not only consumers but competitors as well.

Companies operating in fast-growing markets for consumer goods were the first to receive signals about the changes in the mechanism of formation of competitive advantages and began to experience the concept of market orientation of business. The onset of the phase of strengthening the focus of business on the consumer in different sectors of the economy is substantiated by two factors: 1) the maturity of markets and saturation of the needs of the main market; 2) acceleration of the diffusion rate and penetration of the technological process (Lambin \& Schuiling, 2012). Tightened competition, saturated demand, increased requirements of consumers and intermediaries, etc. can motivate to strengthen the company's marketing orientation.

The intensity of competition in food markets is increasing as a result of the economy globalization, growth of value of food products, oversupply of agricultural products in 
affluent economies, less predictable consumer behavior, increasing concentration in the retail sector. In such conditions, food companies need to be market-oriented. Market orientation is regarded as something desirable, something that the food industry lacks, and something that could help it to build a better competitive position for the future (Grunert et al., 1996). Marketing orientation of the food enterprise enables to form successfully competitive advantages in the conditions of the modern agrarian market. Just the awareness of senior management of the need to use marketing at a strategic level allows companies to gain significant competitive advantages.

Only companies having competitive advantages that are based on the efficiency and productivity gained through the use of advanced science-based technologies and offer unique products and services can be successful under current competition. Porter, 1998). The company must be able to develop, produce and sell the product more efficiently than competitors, be able to organize the entire cycle of operations with the product from its development to sale to the final consumer at a lower cost and in a shorter time. In addition, the company should stand out from the competition, offering customers a product that has either a high level of quality with a standard set of parameters that determine this quality, or a non-standard set of properties that really interest the buyer. This can be achieved through marketing orientation and the use of marketing tools.

Competitive advantages are formed under the influence of many factors that companies achieve when forming a market strategy. In modern global economy, sustainable competitive advantages are more based on local things like knowledge, relationships, motivation that distant business rivals cannot respond to (Porter, 1998). This necessitates the formation of clusters to ensure the achievement of high competitive success by the companies in certain sectors of the economy.

A cluster is treated as a group of geographically close companies and related organizations at the city, region, country, or multi-country level (Enright, 1993). Companies and related organizations operate in a particular economic sector and complement each other facilitating the increase of the regional output, improvement of the human welfare and optimization of the spatial organization of the territory, attraction of the investments and increase of the competitiveness of the regional economy.

In our study, Ukrainian oil and fat market has been studied as as part of the agri-food market. Its specificity is based on the fact that integrated agri-food companies have the highest efficiency of economic activity under conditions of transformational economy in the domestic and world markets for agrarian and food products. Such companies provide their participants with the access to the use of common resources, redistribution of resources between structural units operating on one financial result, and possible losses of one enterprise are compensated by the profit of the integrated group as a whole (Tanasiichuk et al., 2019). Due to high profitability, oil and fat business in Ukraine is quite attractive to foreign investors, so most vegetable oil and fat producers are controlled by the multinational integrated companies that have a simplified financial management due to easy access to the global capital market (Zavorotniy \& Bilyk, 2017). However, nowadays the main factors of high efficiency of companies are no longer a better access to input resources or the scale of individual enterprises. Establishment of agri-food clusters can be considered to be one of the solutions for the providing competitive advantages for the Ukrainian oil and fat business. 
Agri-food clusters are formal and informal participants in the interaction and intersectoral cooperation of producers and institutions aimed to achieve mutual benefit in the field of food and agricultural production (Gálvez-Nogales, 2010). Agri-food clusters enable to achieve unique competitive advantages of geographical areas and companies, provide improvement of sector systemacy and enhancement of economic efficiency (Feldman \& Audretsch, 1999). Oil and fat companies in the food industry can gain sustainable competitive advantages due to integration efforts aimed to form oil and fat clusters in the local geographical areas from all stakeholders and relationships in the supply chain of oil and fat products including suppliers, manufacturers, intermediaries, consumers, government and other organizations, etc.

Effectiveness of the integrated cluster will depend on the adequate application by oil and fat companies of the tools of the modern marketing concept of the market-oriented and consumer-oriented business based on consideration of the interests of everyone who is directly or indirectly involved in the oil and fat business, local community and society. The success of future oil and fat clusters requires an in-depth study of market characteristics, current relationships and interests of all stakeholders in the supply chain within the local geographical area, which is the purpose of our study.

\section{Results and Discussion}

In the late twentieth and early twenty-first century, American and European agri-food companies were among the first to widely apply the marketing-oriented concept of business organization, which was their reaction to the results of marketing research on the dynamics of the consumer market and forecasting trends. In affluent economies in the food market, there was a situation where food supply exceeded the demand. This was due to the increased productivity of companies and globalization of the market. Food companies faced the maturity and saturation of the domestic markets. In the consumer oil and fat market, the situation is identical to the one described above. In conditions of the saturation of the oil and fat market, the behavior of the end consumers and their preferences and requirements for oils and fats have changed. Due to this, oil and fat companies have been forced to change existing marketing strategies in the domestic markets and/or look for new markets and new strategies.

The growth of the world's population and diversification of the use of oil and fat raw materials towards biofuel production have dramatically changed the global oil and fat market. Domestic consumer markets of edible oils and fats in affluent economies have become saturated, and consumers have become more demanding for edible oil and fat products. However, there is a significant increase in the demand for oils and fats for food, feed and industry in Asia, Africa and the Pacific region. In affluent economies, there is an unsatisfied demand for "healthy" edible oils and fats, oil and fat raw materials for the oil and chemical industry and biofuel production.

The world's leading producers and suppliers of high-quality stable vegetable oils and fats owe their success to close cooperation with consumers in order to find individual solutions and create innovative products. They combine the achievement of their business goals, their differentiation in the markets with the tastes and preferences of customers. They are marketing-oriented. The marketing orientation of the oil and fat 
business management at the consumer involves constant marketing research of his needs, desires, tastes and preferences. The most effective use of the marketing information obtained enables to create a competitive advantage, namely, unique consumer usefulness of the offered oil and fat products through the needs satisfaction by the means that are better than those of their competitors. Since maintaining of product uniqueness over a long period of time in modern global world is challenging, businesses need to constantly develop and implement innovative products and marketing processes. In the world and domestic market of vegetable edible oil and fat products, the tastes and preferences of consumers are changing. Step-by-step, the behavior of individual Ukrainian consumers is gradually changing and the preference is given to "healthy" edible oils and fats. The domestic market of traditional oil and fat products passes from the stage of saturation to the stage of maturity.

In such conditions, favorable natural and climatic conditions of Ukraine, profitable logistics location of oil and fat Ukrainian companies and availability of the stable raw material base for production have provided opportunities for the formation of competitive advantages. However, these benefits are not entirely sustainable, as in most cases they involve cheap labor, low prices for oilseeds and products of its primary processing.

The domestic Ukrainian market of oil and fat products is quite saturated. Today, its specificity is largely determined by the focus of agricultural companies on the predominant export of oilseeds. The main oilseeds grown in Ukraine are sunflower, soybean, rapeseed and flax. More than half of the domestic production of oilseeds is exported. Oilseed producers export through large grain traders. The total oilseed exports are likely to continue to grow that is caused by the reduction in Ukraine's export duty on sunflower and flaxseed from 5.5\% in 2020 to $0 \%$ in 2026 due to Ukraine's international commitments undertaken in the framework of free trade agreements with the EU, the countries of the European Free Trade Association and Canada. There is currently no export duty on soybean and rapeseed.

The key players in the market of oilseeds, oils and fats in Ukraine are groups of integrated international and domestic companies that have large production facilities for oilseeds and logistics of raw materials and products such as Bunge Group, Cargill Group, Kernel Group, Myronivsky Hliboproduct Group, Vioil Group, etc. Their share in the total processing of oilseeds in the last few years ranged within $75-80 \%$. The same companies are the main exporters of oil and fat products, the export of which comprised more than $\$ 3$ billion in 2018 .

Agricultural oilseed producers, processing enterprises and intermediaries are the main elements of the supply chain of oil and fat products in the trajectory of "production of raw materials - processing-consumption" [Figure 1].

This chain includes specialized storage and transshipment companies, crushing and refinery companies, animal fat companies, fat compounders, transport companies (motorway, railway and waterway), food companies, feed businesses, oil and chemical industry, biofuel manufacturers, specialized service providers, researchers, laboratories, etc. 


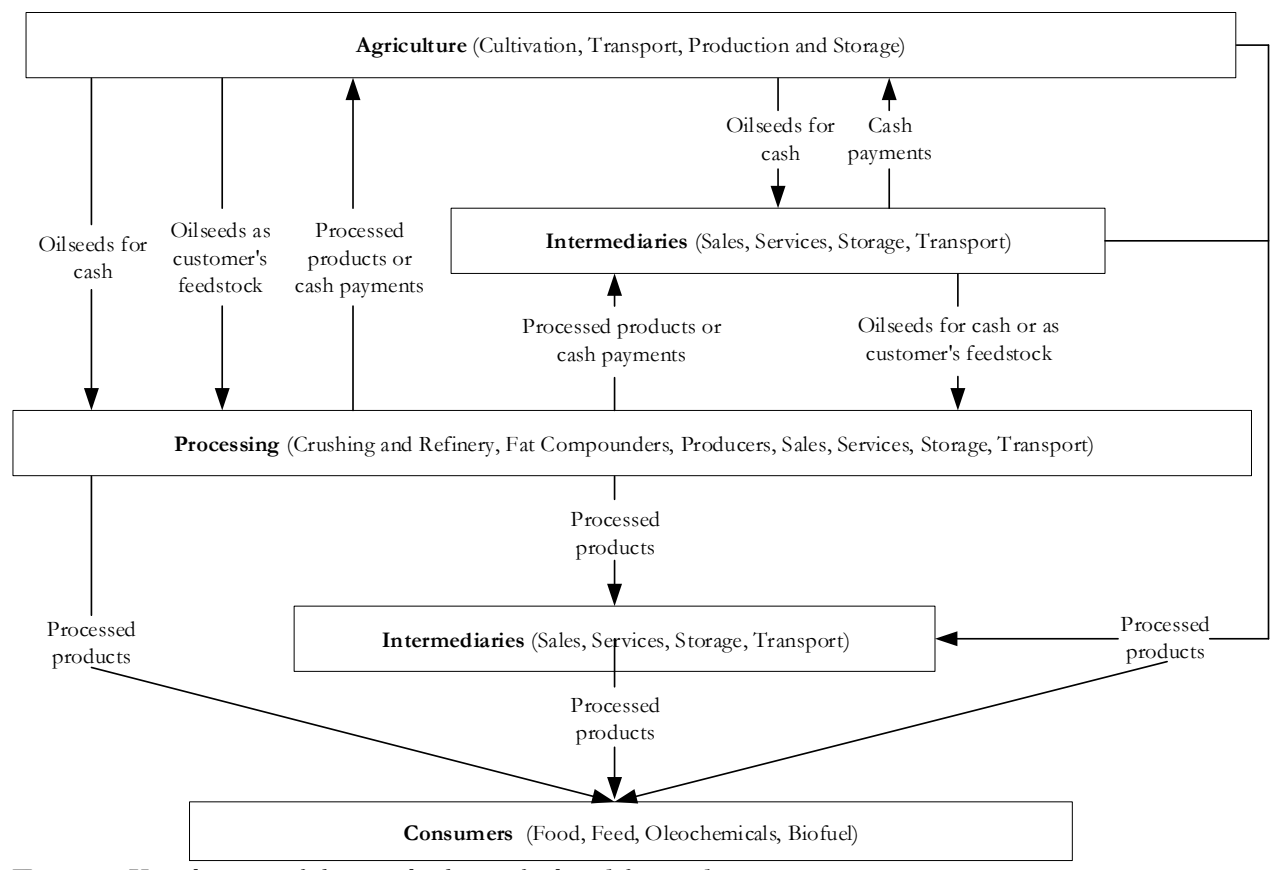

Figure 1. Key elements of the supply chain of oil and fat products

According to the type of the product manufactured (raw materials, oil and fats, products of their processing), domestic Ukrainian oil and fat producers are divided into the following ones:

a) Agricultural and agri-industrial enterprises that produce oilseeds as raw materials for further individual processing or for sale. The total land area under oilseeds in Ukraine in 2018 amounted to 9.1 million hectares; the cropping area under oilseeds at some enterprises ranges from a few hundred at small and middle-sizes enterprises to several thousand hectares at agricultural holdings; gross yield of oilseeds in 2018 amounted to 21.4 million tons.

b) Processing enterprises that process vegetable oil raw materials for the production of final consumption products (B2C) and/ or raw materials for further deeper processing or sale (B2B). In 2018, these enterprises processed 12.7 million tons of oilseeds.

Ukrainian producers of oil and fat products can be divided into three main groups. The first one is represented by the specialized companies producing oil and fat products, i.e. oil and fat plants or industrial complexes. The second group includes small companies producing vegetable oil, i.e. oil mills that are departments of plants for which vegetable oil production is not the main activity or oil mills that operate independently. The third group involves producers of other oil and fat products, e.g. margarine and soap factories and industrial complexes.

An important element of the supply chain of oil and fat products and creation of the added value is storage and transportation. Small and medium-sized producers do not have their own significant capacity for storage, primary processing of raw materials and production of oil and fat products, and therefore they transport and store them in the 
elevators of grain traders or processing companies. High transportation and storage tariffs force producers to sell raw materials and products in the early stages of the logistics chain.

The activity of different kinds of intermediaries in the supply chain is an essential element of the market of agricultural products and processed products in all countries having market economies. Oil and fat industry is not the exclusion. Their activity is estimated rather ambiguously: on the one hand, they can release oilseed producers from the functions of sales, save their money on selling, perform trade operations by qualified personnel, provide faster and cheaper movement of oilseed and products of its processing from producers to consumers, and on the other hand, agricultural enterprises lose direct contacts with the markets, the activity of intermediaries causes significant unjustified increase in the cost of feedstock and finished products.

The necessity to sell processed products through intermediaries is explained by the organizational and administrative barriers, e.g. lack of the developed wholesale market of oilseed and products of its processing in the Ukrainian local geographical areas, marketing services and other market infrastructures, underdeveloped information support concerning market prices and producers. It slows down and complicates the process of product movement to the final consumer, settlements and payments. In addition, intermediary structures, unlike other players of the market of raw materials and finished products, pay immediately after shipment, which is an important factor in choosing a buyer by the manufacturer, considering the lack of working capital for the production process. Manufacturers often reduce selling prices for products in order to attract intermediaries.

All the above-mentioned business entities provide managerial, organizational, logistical, informational, financial and other support for the supply chain of oil and fat products. Therefore, a system of close relationships has been formed around oil and fat enterprises within the supply chain [Figure 2].

According to the scheme, the system of economic relations covers relations between partners (organizational, financial, technological) and production-contract relations (production, harvesting, processing, sales, agri-service) as well as the economic mechanism of development and improvement of relations in oil and fat industry.

The development of mutually beneficial economic relations between the companies of the Ukrainian oil and fat industry is complicated by the unregulated organizational and economic mechanism of relationships between them and the imbalance of interests of oilseed producers, processors, intermediaries, logistics and other stakeholders.

The basis of economic relations between oilseed producers, its providers, processors, trade and logistics providers are product prices, tariffs for services (transportation, storage, processing), conditions of mutual settlements, material incentives, responsibility of the parties for the obligations taken, etc. That is what largely determines the possibility of profitable business activity, establishment of strong economic relations, and fulfillment of obligations. The key to effective and close relationships is the rapprochement of participants in any product segment, consistency and realization of their mutual interests. 


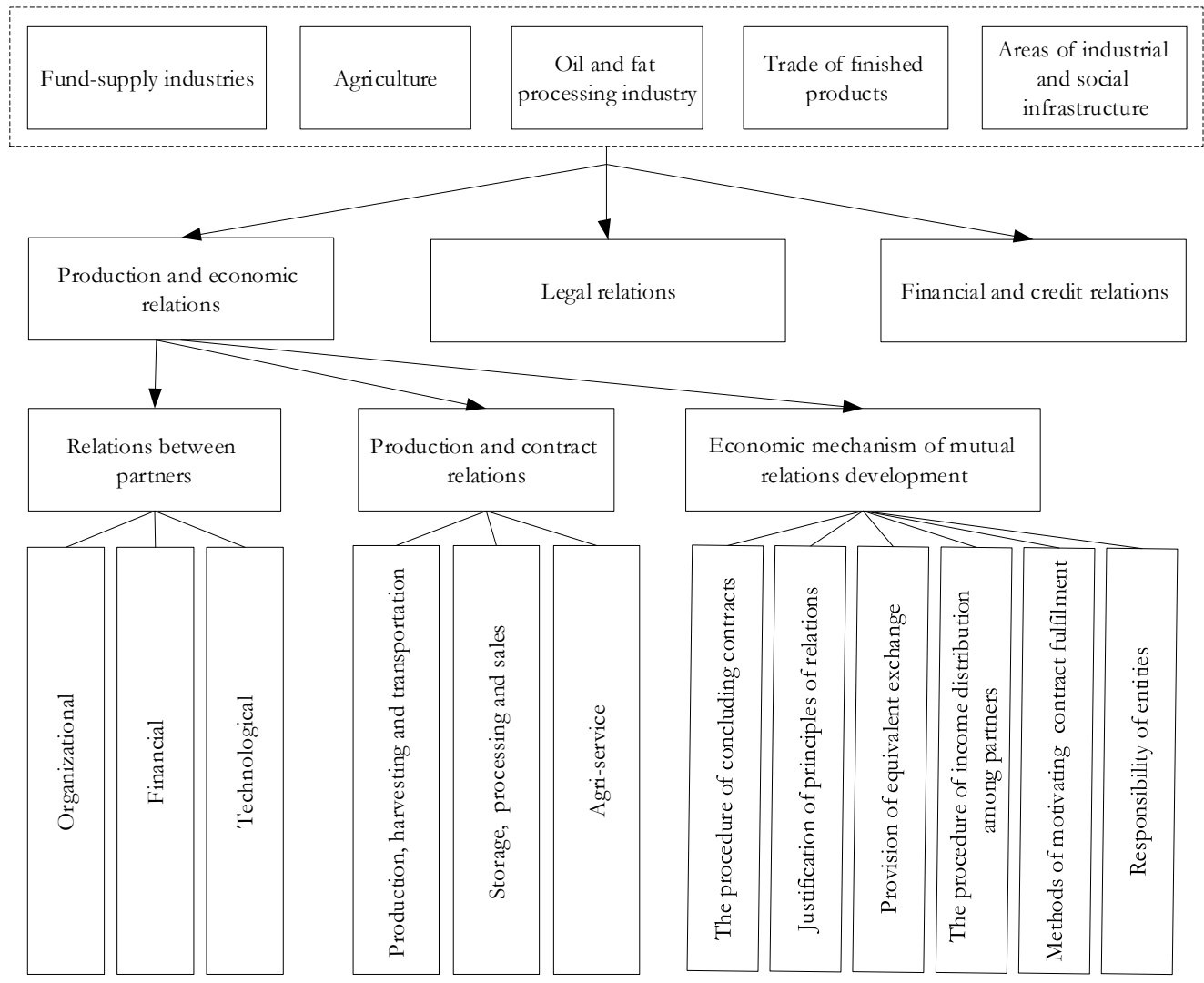

Figure 2. Relationships in oil and fat industry

In practice, the Ukrainian oil and fat business operates in the mode of organizational separation of interests of various business entities. This does not allow oil and fat companies to form a stable raw material base effectively, to develop a stable system of mutually beneficial economic relations with the members of the supply chain, who often expect to obtain maximum profits in the short term.

In such conditions, the main share of the profit is formed at the stage of obtaining the final product and its sale. The cluster approach allows to form the mechanism of relationships (direct and inverse economic relations), which enables to obtain the profit that is equivalent to costs, not only to those entities that sell the final product, but also to all participants of the supply chain.

Traditional management of oil and fat companies having such competitive advantages as low prices for raw materials and products and export orientation, ceases to be highly efficient. Until recently, due to the internal transformational economic reformations and the specifics of the oil and fat market, marketing approaches to management aimed at improving production, goods, commercial efforts have been clearly expressed for Ukrainian companies. The cropping areas and production capacities of processing enterprises are increased, high-yielding varieties of oilseeds are used, seed oil content is increased, logistics infrastructure is improved, new cultivation and processing 
technologies are introduced in Ukraine. However, in our opinion, this is only a shortterm unstable competitive advantage. All this creates the potential for the formation of sustainable competitive advantages, but the next steps are needed for its implementation, which should involve marketing orientation of the oil and fat business based on clustering.

In the modern world stable competitive advantages are achieved through the marketing orientation of business and consideration of the interests of all participants of the supply chain and stakeholders [Figure 3].

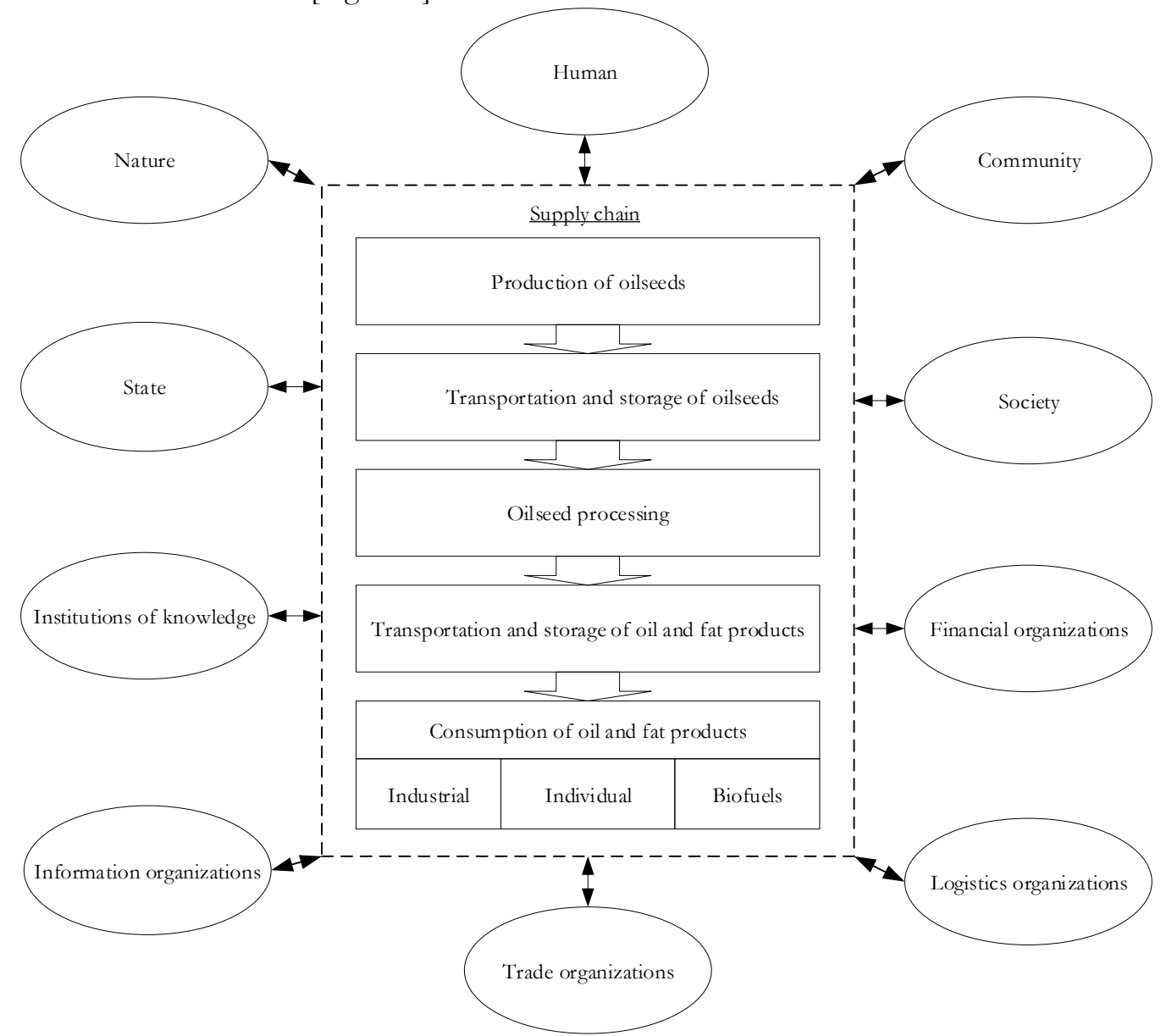

Figure 3. Supply chain of oil and fat products and stakeholders

Along with the interests of private businesses in the supply chain of oil and fat products, there are interests of individual consumers, the state, society, which should not enter into unresolvable conflict with each other, provoke opposition.

For example, in Ukraine, one of the urgent problems is the failure of oilseed producers to comply with agricultural technological recommendations of scientists on the cultivation of oilseeds, which leads to significant soil depletion. Return of oilseeds to crop rotation before scientifically justified terms leads to a sharp deterioration of the 
phytosanitary condition of the fields, accumulation of infections, diseases and pests in the soil, as well as drying of the soil, excessive removal of nutrients from the soil, increased humus mineralization. Small and medium-sized producers are abusing this. This is even more widely practiced by the agricultural holdings that grow oilseeds under inadequate crop rotation for 4-5 years in one local geographical area, and then, when the crop yield decreases, change it to another. State institutions and society are interested in the stable economic growth and improvement of the human well-being, and local communities receive significant revenues from the oil and fat business to the local budgets. Nevertheless, the damage to land from the irrational extensive cultivation of oilseeds is attracting more and more attention of the community, local and state politicians. As a result, oil and fat companies and their lobbyists face resistance and barriers at both regional and national levels.

Another important issue for the oil and fat business is the ethics and safety of the use of GMO raw materials in the production of oil and fat products. The possibility of their use is a problem that is still widely discussed in terms of the ethics of existence in general (unnatural impact on plants), food safety (safe and healthy food production and food security (availability and access to food). Transgenic biotechnologies used for the cultivation of agricultural oilseeds can significantly increase plant productivity, resistance to diseases and pests, adverse climatic conditions, increase seed oil content, reduce the content of saturated fatty acids in oilseeds.

However, for example, governments and oil and fat companies in the European Union, despite investing heavily in biotechnology and implementing policies in recent decades to stimulate a knowledge-based economy, still use precautionary principles regarding the use of GMOs in food that is caused by the ambiguity of social perception and the likelihood of their danger to human health.

Economic interests collide with social ones (ecology and environmental protection, social and transport infrastructure of local communities, etc.), and therefore it is necessary to find a compromise between the desired profitability of business, maximum satisfaction of consumers and local communities and society.

The most effective results for the enterprise are provided by the use of marketing management concepts that are oriented at identifying and meeting consumer demand as well as consideration of the interests of all other stakeholders in the supply chain of oil and fat products, the individual, community and society, i.e. concepts of relationship marketing and holistic marketing.

Oil and fat cluster combines the processes of production of raw materials, processing and sale of products into a single chain. Due to investments and high-tech innovations, the joint activities of the cluster entities will increase the competitiveness of oil and fat products in the domestic and foreign markets, help to form and develop infrastructure of the geographical area, increase employment and income, improve product quality and environmental situation.

In our opinion, in order to achieve stable competitive advantages and success, Ukrainian companies should become a part of the supply chain as well as the participators of the sustainable successful development of the local geographical area, its community and society, i.e. the oil and fat cluster [Figure 4]. 


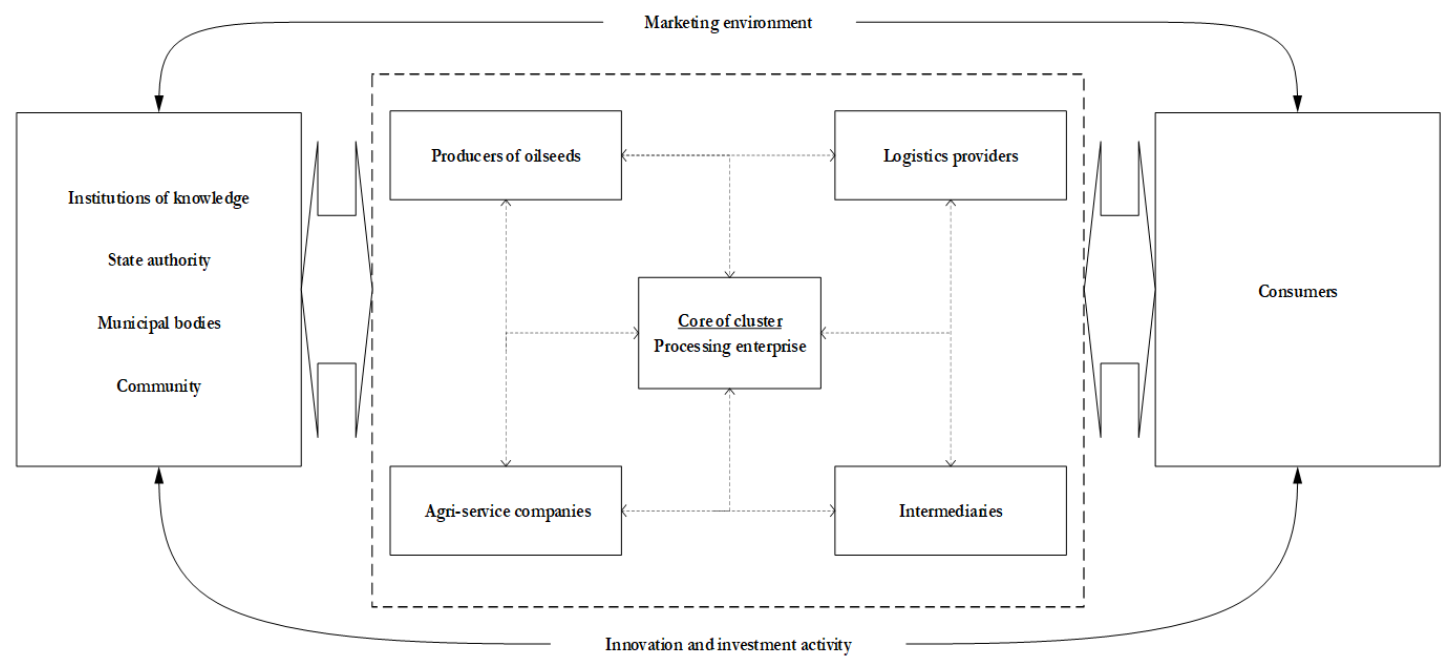

Figure 4. Oil and fat cluster

Oil and fat cluster is a territorially localized, innovation-and-investment oriented and integrated structure organized on the basis of the industrial enterprise. The purpose of the cluster is to create a basis for increasing the competitiveness and productivity of the food sector of the geographical area, redistribute added value in the supply chain and ensure integrated implementation of socio-economic potential of the territories.

The structure of the oil and fat cluster includes four interrelated and interdependent elements, which determine the competitiveness of the products of oil and fat industry and stability of the position of these products in the domestic and international markets. The first element of the cluster is processing enterprises, which are the core of the cluster, which process oilseeds and provide the community with high quality oil and fat products and provide opportunities for the development of external exchange. The second element of the oil and fat cluster includes enterprises that supply oilseeds, and the effective operation of which depends on the quality of finished products of oil and fat industry produced in the cluster. The third element of the cluster is intermediaries and logistics providers who help the cluster to develop the system of promotion of oil and fat products. The fourth element of the cluster unites state authorities and municipal bodies, community and institutions of knowledge. Profitability of small and mediumsized enterprises, the amount of tax revenues to the budget, the development of opportunities for innovations, and, in general, the balanced development of the community depend on their involvement in the functioning and development of the cluster. A special position in the cluster is occupied by the institutions of knowledge, which determine the level of training of future highly qualified specialists, the effectiveness of innovative solutions of research institutions and the success of innovation transfer.

The feature of oil and fat is that mutually beneficial cooperation of the above-mentioned elements provides a synergy effect, which directly affects the formation of innovation and investment activity of each element of the cluster as a basis for the intensification of the potential of its business participants and formation of their sustainable competitive advantages. 


\section{Conclusions}

Due to globalization processes in the development of the world economy, food companies need to find new ways of forming new competitive advantages and maintaining current ones. These tendencies have increased the interest of food producers in food products having higher added value as well as in the research and development of new products and processes. Development and introduction of such products require mutual efforts of all stakeholders and considerable investment resources, which can be achieved by strengthening marketing orientation of the oil and fat business and establishment of agri-food clusters.

Establishment of oil and fat clusters in Ukraine will help to improve economic, organizational and legal relations that have developed between business participants of the supply chain of Ukrainian oil and fat products and all other stakeholders in the process of creating added value.

Reaching a compromise between the interests of all stakeholders of the oil and fat cluster will bring together oil and fat business entities to organize competitive production at each stage of the technological chain, facilitate formation of marketing structures taking into account market conditions, strengthen export potential, attract foreign investments, ensure implementation of up-to-date technologies to expand the assortment and improve food quality and safety to meet the current and future domestic and international consumer demand.

\section{References}

Ansoff, H.I. \& McDonnell, E.J. (1988). The New Corporate Strategy. New York: Wiley.

Dikson, P. (1997). Marketing Management. Fort Worth: Dryden Press.

Enright, M. (1993). The Determinants of Geographic Concentration in Industry. Working paper 93-052, Harvard Business School, Boston, Mass.

Feldman, V.P. \& Audretsch, D.B. (1999). Innovation in Cities: Science based Diversity, Specialization and Localized Competition. European Economic Review, 43(2), 409-429.

Gálvez-Nogales, E. (2010). Agro-based clusters in developing countries: Staying competitive in a globalized economy. Occasional Papers No. 25, FAO-Agricultural Management, Marketing and Finance, Rome.

Grunert, K.G., Larsen, H.H., Madsenn, T.K. \& Baadsgrard, A. (1996). Market Orientation in Food and Agriculture. Boston: Kluwer Academic Publisher.

Kotler, F. \& Armstrong, G. (1991). Principles of Marketing. N.J.: Prentice Hall. Englewood Cliffs.

Lambin, J. \& Schuiling, I. (2012). Market-Driven Management: Strategic and Operational Marketing, UK: Basingtoke. Palgrave Macmillan.

Porter, M.E. (1998). Clusters and the New Economics of Competition. Harvard Business Review, 76 (6), 77-90.

Porter, M.E. (1985). Competitive Advantage: Creating and Sustaining Superior Performance. New York: The Free Press.

Schumpeter, J. (1934). Theory of Economic Development: An Inquiry into Profits, Capital, Credit, Interest, and the Business Cycle. Harvard University Press, Cambridge, MA.

Tanasiichuk, A., Hromova, O., Abdullaieva, A., Holovchuk, Y. \& Sokoliuk, K. (2019). Influence of Transformational Economic Processes on Marketing Management by an International Diversified Conglomerate Enterprise. European Journal of Sustainable Development, 8(3), 448-454. https://doi.org:10.14207/ejsd.2019.v8n3p448.

Zavorotniy, R. \& Bilyk, O. (2017). Transformation of sunflower oil production in Ukraine due to acute economic crisis. Journal of International Studies, 10(1), 225-236. https://doi:10.14254/2071$8330.2017 / 10-1 / 16$. 